\title{
A Perczel-glóbusz újraalkotásának legújabb fázisa
}

Márton Mátyás
DOI: https://doi.org/10.30921/GK.71.2019.5.3

Absztrakt: 2019-ben egy féléves projekt keretében mód nyílt az Eötvös Loránd Tudományegyetem Térképtudományi és Geoinformatikai Tanszékén 2008 és 2012 között folyó, majd 2013-tól szunnyadó, a Perczel-glóbusz újraalkotásával kapcsolatos kutatások és elóállítási munkák folytatására. A legújabb kutatások meglepó eredményeket is feltártak. A mind a magyar, mind a nemzetközi irodalomban 1:10 milliós méretarányú, $132 \mathrm{~cm}$ átmérójú földgömbként ismert Perczelglóbusz átmérôje „csupán” 127,5 cm! Érdekes eredménnyel járt a naptárkeret részletes vizsgálata is. Ennek során a magyar nyelvben ma már nem használt negyedrendú égtájmegjelölések teljes körének feltárására került sor (például: „Nyugathozi E. ”, „D.N. Dél” vagy „Kelethezi D.K.” stb.). Ezek az égtájmegjelölések az angol nyelvben jól ismertek (például: "north by west”, „southwest by south” vagy „southeast by east” stb.), de a mai magyar nyelv nem ismeri ezeket. A most elvégzett munka során összesen 2872 rajzi és 3252 névrajzi kiegészités, pontosítás történt. 318 helyen - zömmel a glóbusz sérült részein - került sor a summer (az árnyékolt domborzatrajz) pótlására, illetve kiegészitésére.

Abstract: The Department of Cartography and Geoinformatics of Eötvös Loránd University continued the research and production work related to the re-creation of Perczel's globe in the framework of a half-year project in 2019. The original project ran between 2008 and 2012, but it lied dormant since 2013. Recent research has also revealed surprising results. For instance, the diameter of Perczel's globe is $127.5 \mathrm{~cm}$ only-however, it is known as a globe of one to ten million scale and of $132 \mathrm{~cm}$ diameter in both Hungarian and international literature! An in-depth review of the horizontal calendar frame of the globe also brought an interesting result: a full range of third-rate intercardinal points (32-point compass card) not used in the modern Hungarian language has been explored (for example, "Nyugathozi É", "D.N. Dél" or "Kelethezi D.K."). These celestial directions (for example, "north by west", "southwest by south" or "southeast by east") are still well known in the English language, but they are unknown in Hungarian today. A total of 2872 drawings and 3252 names have been completed during the latest phase of the research. The shaded relief was replaced or supplemented in 318 places - mostly in the damaged parts of the globe.

Kulcsszavak: digitális, egykorú vagy korabeli hasonmás; állapotrögzítô digitális hasonmás; restaurált, digitális, tartalmi hasonmás; digitális virtuális restaurálás; digitális virtuális rekonstrukció

Keywords: digital, contemporaneous facsimile; digital facsimile record of condition; restored, digital facsimile of content; digital virtual restoration; digital virtual reconstruction

\section{Elözmények}

Közvetlenül a Virtuális Glóbuszok Múzeumának (VGM, http: terkeptar. elte.hu/vgm) 2007-es megalapítását követôen (Márton-Gede-Zentai 2008) megfogalmazódott bennem az a terv, hogy 2012-re, Perczel László 1862-re datált kéziratos óriásglóbusza elkészültének 150. évfordulójára hallgatók bevonásával az Eötvös Loránd Tudományegyetem Térképtudományi és Geoinformatikai Tanszékén elkészítsük annak digitális, egykorú vagy korabeli hasonmását, miután a mai állapot rögzítése megtörténik a VGM számára (Márton 2008).

Már 2008-ban, majd ezt követôen éveken át több alkalommal is pályázatokat nyújtottam be kutatást (pl. OKTA - Országos Tudományos Kutatási Alapprogramok) vagy kulturális értékek megốrzését támogató (pl. NKA - Nemzeti Kulturális Alap) intézményekhez, nagyvállalatokhoz (pl. MOL
- Magyar Olaj- és Gázipari Nyrt.), sốt magánszemélyekhez is. A cél az volt, hogy lehetôség adódjon a munka minél teljesebb elvégzésére, ideértve egy kézzel fogható, hordozógömbre kasírozott, rézmeridiánba illesztett, állványra szerelt hasonmás elkészítését is. Pályázataim sajnos sikertelenek voltak. [Az egyetlen nyertes, a még 2007 szeptemberében benyújtott és 2008 januárjában elbírált OTKA-pályázatom a VGM megvalósítását támogatta. Ebben már megfogalmaztam a Perczel-glóbusz mai állapotrögzítésének szükségességét és lehetôségét (Márton 2007), a kutatási zárójelentésben pedig beszámoltam annak elkészültérôl is (Márton 2011a).]

2008 májusában közel $900 \mathrm{db}$ nagy felbontású fényképfelvételt készítettünk az Országos Széchényi Könyvtár Térképtárában ôrzött eredeti Perczel-földgömbrôl (Nemes Zoltán, Gede Mátyás, Márton Mátyás és Paksi Judit). Ezek feldolgozásával elkészült a mai állapotot bemutató 3D-s modell a VGM-be (Gede Mátyás, Nyuli Éva, Tóth Bettina, Való Adrienn, Ungvári Zsuzsanna, Szabó Renáta, Zubán Diána és Zsiga Aranka), azaz létrejött a Perczel-glóbusz állapotrögzítô digitális hasonmása (VGM ID 76). Ugyanakkor a fényképfelvételek felhasználásával mód nyílt jpgformátumú, nagy felbontású gömbszegmensek előállítására is (Gede Mátyás). Ezek képezték alapját a hallgatók munkájának, melynek során megszületett a glóbusz restaurált, digitális, tartalmi hasonmása 2012-re (VGM ID 110). Ezeket használta Sziládi József, a hajdanvolt Kartográfiai Vállalat felelős térképszerkesztője is, hogy önzetlen munkával (anyagi ellenszolgáltatás nélkül!) elkészítse a glóbusz csaknem egész területére az árnyékolt domborzatrajzot, a summert.

Öt diplomamunka (Czombos Edit, Mészáros Evelin, Kirisics Judit, Kacsándi László és Zubán Diána 
Erzsébet), hat szakdolgozat (Nyuli Éva, Tóth Bettina, Való Adrienn, Botyánszki Mariann, Kis Bettina és Németh Krisztina Katalin), valamint két TDKdolgozat (Tóth Bettina-Való Adrienn és Kirisics Judit) született a feldolgozással kapcsolatban. Az így megalkotott szelvényekból állt össze 2012-ben a VGM-be is felkerülő restaurált és kis részben rekonstruált digitális, tartalmi hasonmásföldgömb (Márton 2012a). Öt fontos, zömmel többszerzôs publikáció látott napvilágot magyar vagy angol nyelven a témával kapcsolatban (Gede Mátyás, Gercsák Gábor, Márton Mátyás, Ungvári Zsuzsanna), amelyek egy része konferencia-előadásként is elhangzott (Márton 2012b).

Az elért eredmények összefoglaló bemutatására két - idôben nem túl távol esô -, az OSZK-val közös, és a Budavári Palotában tartott konferencián is sort kerítettünk. Természetesen a folyó munka mindenkori állásának megfelelô ismertetést adtunk: 2011. március 18-án a „Nyomtatott magyar föld- és éggömbök a kezdetektôl napjainkig” kiállítás Néhány szó a glóbuszokról címú zárókonferenciáján (Márton 2011b), valamint a Perczel László készítette földgömb másfél száz éves születésnapját 2012. november 16-án ünneplō Régi és új Perczel-glóbuszok: egy óriásgömb és rekonstrukciója címmel megrendezett konferencián (Márton 2012b).

\section{A faximile vagy hasonmás fogalma}

Szakterületünkön, a térképészetben hasonmáson általában egy korábban megjelent kartográfiai dokumentum (kéziratos, nyomtatott és utószínezett vagy több színnel nyomtatott térkép, atlasz, föld-vagy éggömbtérképnyomat stb.) olyan új kiadását értjük, amely a reprodukálandó mútárgy állapotát mutatja be az új kiadás idôpontjában, és tartalmazza mindazon változások - kopások, szakadások vagy más sérülések, elszínezôdések stb. - képét, amelyeket a megjelenést követóen a reprodukcióig a mútárgy elszenvedett. Az ilyen hasonmás előállítása is többféle módon történhet. Legáltalánosabb és persze a leggyorsabb is, hogy lefényképezzük az eredetit, majd színre bontás után újra kinyomtatjuk (hagyományos hasonmás). Vagy nagy felbontású szkennerrel állítjuk elố a képét (digitális fakszimile), amelyet akár kinyomtatva, akár képernyôképként is tanulmányozhatunk. Ebben az esetben már lehetôség adódik az idôk folyamán bekövetkezett sérülések, esetleg elszínezôdések eltüntetésére, különösen akkor, ha több példány is ismert a kiadványból (digitális restaurálás). A hasonmás előállításának olyan módozatai is lehetségesek, amikor a készítéskori állapotát próbáljuk rekonstruálni. Ilyen mód lehet, hogy a készítés eredeti technológiáját használva újraalkotjuk mútárgyunkat (technológiai fakszimile). Ebben az esetben sem szükségszerú, hogy a mútárgy élete folyamán elszenvedett károsodásokat is reprodukáljuk! Ám akár modern, számítógépes technológiát alkalmazva is újrarajzolhatjuk, színezhetjük, névrajzát modern betûkészleteket használva újraírhatjuk. És így tovább. Ebben az esetben azonban „csak” digitális tartalmi hasonmásról beszélhetünk. A különbözô elóállítási módszerek eredményeként létrejövô hasonmások azonban ugyanazon mútárgy esetében sem feltétlenül azonosak!

A Perczel-glóbusz esetében 2008ban állapotrögzítô hasonmás készült, amelynek egy kisebb felbontású változata került be a VGM-be, hogy az interneten is kezelhetôen, széleskörú hozzáférést biztosítsunk. Majd 2012-ig olyan egykorú vagy korabeli hasonmás elkészítésével foglalkoztunk, amelynek célja az elkészítéskora-beli feltételezett megjelenés reprodukálása volt, aminek az alapja Ambrus-Fallenbüchl Zoltán (1963a, 1963b) részletekbe menó gömbleírása volt az akkor százesztendôs, de még nem „restaurált” glóbuszról, az 1960-as évek elejérôl. Mivel ez utóbbi feldolgozás a modern technológiát használó változat (az elôbb felsoroltak közül), így csak tartalmi hasonmásról beszélhetünk, hiszen a névrajz - ugyan betû́rôl betû́re egyezốen, de - nem Perczel kézírását reprodukáló rajzolatú.

Kis kitérôképpen érdemes itt rögzíteni az 1978 körül elvégzett „restaurálás" tényét és körülményeit, mert ismereteink szerint semmilyen dokumentáció nem maradt fenn, és az idố múlásával a szemtanúk is fogyatkoznak. A munka az akkori Térképtudományi Tanszéken Stegena Lajos tanszékvezetố professzor irányításával, a Ludovika épületének 2. emeletén zajlott, ahová daruval kellett a glóbuszt beemelni. A réz meridiánkör ekkor is deformálódhatott, de valószínúbb, hogy a gömböt a restaurálás során - a meridiángyúrú felsố részére kötözött erôsebb huzal vagy kötél segítségével - az állványzatból is kiemelték, hogy hozzá lehessen férni a megrogyott állványzathoz, annak megerôsítése céljából. A terhelés a gyúrút deformálta. A kiemelést követôen a meridiángyưrû́t minden bizonnyal le is szerelték (talán a deformálódását próbálták helyrehozni), és tévesen helyezték vissza, mert ma a fokmegírások „fejen állnak". A gyưrú deformációja és helytelen visszaszerelése következtében a gömb a sérülés veszélye nélkül nem forgatható, mert bizonyos helyzetekben hozzáér a meridiángyúrúhöz. A gyưrû́ kis keresztmetszeténél fogva arra sem alkalmas, hogy a glóbuszt a talppal 66,5-os szöget bezáró - gyakran alkalmazott, a földtengely ferdeségének megfelelố - helyzetbe állítsuk. Ez az állás azonnal deformálná a meridiángyúrû́t a gömb nagy tömege miatt (Márton 2008). A terhelést egyébként a függôlegesen álló és az állványra támaszkodó tengely viseli.

Visszatérve a restauráláshoz: a földgömböt a tanszéki termekhez, szobákhoz vezetố folyosón helyezték el, ahol egy „fiatalember” (egyes emlékezók szerint egy fizikus hallgató vagy aspiráns) végezte a restaurálást (Hegedüs 2019). A nagyon sérült glóbuszterületeket egyszerúen fehér lapokkal fedték, amelyeken csak a fokhálózat rajza szerepelt. Ezeket a pótlásokat fiatal tanszéki kollégák rajzolták meg (Verebiné Fehér 2019). Mint látni fogjuk - a 2019-es digitális restaurálás és rekonstrukció során -, bebizonyosodott, hogy a gömbfelületrôl levált (vagy tudatosan leválasztott?!) rajztöredékeket igyekeztek visszakasírozni a glóbuszra. Ez nem mindig a megfeleló helyre történt.

Eredetileg az állvány - s vele a földgömb - a lábaira szerelt görgốk segítségével volt mozgatható, de 
ezeket leszerelték. Ma, az OSZK-ban, egy görgós dobogóra van helyezve a glóbusz.

A „restaurálás” során elkövetett talán legnagyobb baklövés a védô lakkréteghez használt anyag kiválasztása volt. A százéves gömb, 1962ben, Ambrus-Fallenbüchl (1963a) leírása szerint „finom lakkréteggel van bevonva”. Az 1970-es évekbeli restaurálás során felvitt védő lakkréteg viszont mára annyira besárgult, megbarnult, hogy az eredetileg vörös színnel ábrázolt településjelek és -megírások szinte teljesen belevesznek, nagyon sok helyen olvashatatlanná váltak.

\section{A folytatás}

A „Perczel-fronton” 2012 után érdemi elốrelépés hosszú ideig nem történt. 2013-ban nyugdíjba mentem. Ugyan több féléven át tanítottam még, de hallgatói érdeklôdés sem mutatkozott a munka folytatására. Két érdeklôdô maradt csupán, akit a kérdés foglalkoztatott. Az egyik Lente Zsuzsanna restaurátor múvész volt, aki már a 2012-es konferencián elhangzott előadásán külföldi példákat is idézve - felvetette a továbblépés szükségességét, fontosságát és lehetôségét (Lente 2012). A másik magam voltam, vagyok, aki máig nem adtam fel Perczel földgömbjének minél mélyrehatóbb restaurálását és rekonstrukcióját, valamint a virtuális változaton túl egy fizikai valóságában is létezô Perczel-földgömbhasonmás létrehozását.

2015-ben egy esetleges szponzor megbízottjaival indultak tárgyalások a Perczel-projekt folytatásának és teljes megvalósításának feltételeiről. A tárgyalások többször megszakadtak, a szponzor képviselôi állandóan változtak, telt-múlt az idô. 2018-ban a tárgyalások végül felgyorsultak, megszületett a megállapodás a személyét feltárni továbbra sem kívánó szponzor legújabb képviselóivel, amelynek eredményeképpen különbözó feladatok elvégzésére hathónapos szerzôdést kaptam. A továbbiakban - a megállapodás szerint - csak a szerzódésben foglalt feladatok megoldására, a született kutatási eredmények ismertetésére szorítkozom.

\section{A feladat}

A megbízás az alábbi feladatok elvégzésére szólt:

- Az ELTE Térképtudományi és Geoinformatikai Tanszékén, illetve a Tanszék és egy adott cég között a glóbusz elektronikus anyagának átadásáról szóló, 2018. augusztus 17-én kelt, Zentai László által aláírt Igazolás nyomán a cégnél is fellelhetô archivált munkarészekbôl az OSZK-ban „Régi és új Perczel-glóbuszok: egy óriásgömb és rekonstrukciója" címmel, 2012-ben megrendezett konferencián bemutatott Perczel-glóbuszrekonstrukció előállítása, A0-ás formátumban nyomtatható, 10 fok szélességú fél gömbcikkelyek formájában, külön-külön az északi és a déli féltekére.

- Az eredeti glóbuszról készített nagy felbontású fényképfelvételek vetülethez transzformált képének beépítése az így elôállított fájlokba.

- A Sziládi József által 2008 és 2012 között elkészített árnyékolt domborzatrajz (summer) azon elemeinek fájlokba illesztése, amelyek korábban nem történtek még meg, különös tekintettel a 2012 augusztusában az ELTE számára átadott munkarészekre, illetve a teljes summer lecserélése szürke árnyalatos képekre.

- A fenti módon elôállított cdrformátumú állományok exportálása pdf-formátumba és ezek átadása a cégnek, továbbá az általa megnevezett tervezó grafikusnak.

- A 132 cm átmérójú glóbusz sérült részeinek pótlása (vonalas, felületi térképelemek és névrajz), digitális restaurálása, illetve részleges rekonstrukciója.

A feladat tehát röviden összefoglalva kettôs: digitális restaurálás és digitális rekonstrukció.

Már a munka kezdetén ez kiegészült azzal, hogy átadjuk a Perczel-glóbuszról készített eredeti felvételeket a Perczelkézírást minél tökéletesebben követô fontkészletek megtervezéséhez a tervezó grafikusnak. A munkafolyamat során pedig további kérésekkel (mint például a görbére illesztett szórt nevek alapvonalra illesztését tartalmazó plusz fájlok generálásával, a rajzi és névrajzi kiegészítések külön fájlokba rendezésével) bôvült a feladat.

A munka kezdetén egységes szelvényezési rendszert alakítottunk ki a gyors információcsere és hivatkozások biztosítására. Ferrói rendszerben $-180-0-+180$ fokos elhelyezéssel 01É, ..., 36É, illetve 01D, ..., 36D jelöléssel kezdôdik az egyes 10 fokos szélességú szelvények azonosítása. Az alapfájlok neve ehhez kapcsolódóan tartalmazza a földrajzi koordinátákat is [pl.: $01 \mathrm{D}(-180-170,0-85)$ vagy 36É(170-180,0-85)], de a hivatkozások mindig egyszerúen ebben a rövid alakban történtek (ahogy jelen dolgozat utalásai is).

\section{Restaurált, digitális, tartalmi hasonmás}

A digitális restaurálás esetünkben azt jelenti, hogy a vastag, erôsen elsárgult-megbarnult „védő” lakkréteggel fedett, már a lakkozás elôtti idôszakban sok helyen erôsen megkopott eredeti glóbusztartalom vonalas és felületi elemeit újrarajzoljuk az eredeti színhasználatnak megfelelően. A névrajzi elemek esetében pedig a kézzel megírt földrajzi neveket kibetûzzük, és az eredeti írásképnek megfelelốen rögzítsük, figyelembe véve a betûszám alapján az írásmódot (ha legalább ennek megszámolására vagy a név hossza és a szórás alapján becslésére lehetôség adódik). Perczel ugyanis nem teljesen következetesen, de a kor szellemének megfelelôen törekedett a magyaros írásmódra, így a glóbuszon a név eltérhet a feltételezett forrástérkép írásmódjától, illetve a mai magyaros írásmódtól is. Néhány példát érdemes felidézni a földgömb különbözó részeirôl a mondottak bemutatására; az elsô név Perczelé, a második egy korabeli, német (a Perczel által bizonyíthatóan használt Universal-Handatlas) térképi neve, a harmadik a mai magyaros névhasználat (Cartographia Világatlasz, Bp., 2001): Manotsin szoros (Malaischkin Str./Matocskin-Sar), Kanin fsz (Halbins. Kanin/Kanyinfsz.), Elborrs hegység (Elburs Gb./ Elburz), Persiai Öböl (Persischer Golf/Perzsa-öböl), Ormus Szorasut. (Str. v. Ormus/Hormuzi-szoros), Bab el-Mandeb ut. (Strasse Bab-el-Mandeb/ 
Báb-el-Mandeb), Adeni Öböl (MB. v. Aden/Ádeni-öböl) [25-26É]. Néhány példa még (az amerikai kontinensekrôl): Barrov f. (Barrow Sp./Barrow-fok) [05É], Jukon (Jukon/Yukon) [06É], Maklintok f. (C. Maclintock/-), Yellov Stone (Yellow Stone R./Yellowstone) [09É], Misisipi (Mississippi/ Mississippi) [11É], Hudson utja (Hudson's Strasse/Hudson-szoros), Clearwater (Klarwasser/Eau Claire-tó) [13É], BUENOS AYROS (Buenos Ayros, ill. Buenos Ayres/Buenos Aires) [14D], Rio de la Plata (Rio de la Plata/La Plata) [15D], RIO JANEIRO (Rio de Janeiro/ Rio de Janeiro) [16D]. A névrajz ilyen mélységú, gondos feltárása akár már a digitális rekonstrukció részének is tekinthetô. Az újrafeldolgozás során a névrajz Perczel kézírásához közel álló betúformát adó modern fontok felhasználásával készült.

Összegezve: a restaurálás folyamán tilos tehát az olvashatatlan rajzi vagy névelemek „kitalálása”, ezeket - mint látjuk majd, és a fenti példák is mutatják - csak úgy egészíthetjük ki, ha egykorú forrástérképek igazolják elképzelésünket. Ily módon elóáll egy tartalmi hasonmás, ami színvilágát, rajzi megjelenítését tekintve hasonlít az AmbrusFallenbüchl-féle leírások nyomán kialakítható képhez, azonban az erôteljesebb kopások okozta olvashatatlan térképelemek hiányoznak, vagy csak

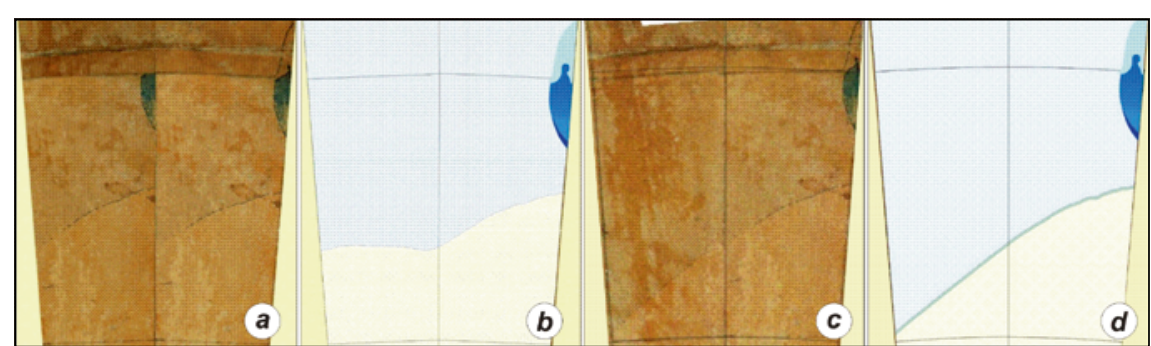

1. ábra. Antarktika partvonalrajzának hibája: a) A hibás montírung;

b) A hallgatói találékonyság rajzi eredménye; c) A korrigált muntírung; d) Az új partvonalrajz

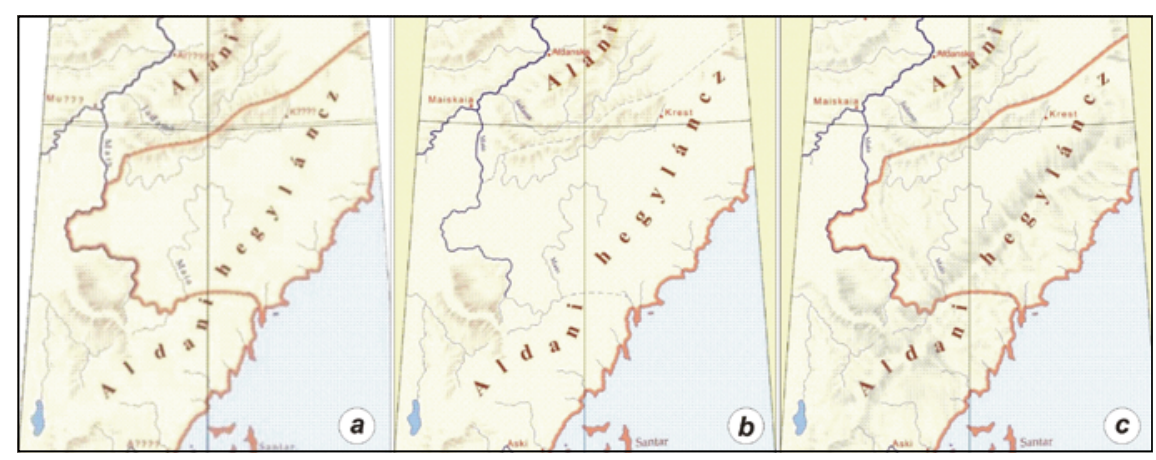

2. ábra. A 34 É szelvény részlete:

a) A 2012-es állapot a VGM-böl; b) Helyreállitás; c) Kiegészítés summerrel

részben szerepelnek. Például a nevek esetében kérdôjellel jelöljük az olvashatatlan betúket.

A digitális restaurálás döntố hányada már 2012-ig elkészült. A feladat ez esetben a korábban végzett munka ellenôrzése, a feltárt hibák javítása, illetve az akkori konferenciát megelôző „rohamka" eredményeinek helyreállítása archiválása akkor nem - Az Antarktika partvonalrajzánál találtunk olyan hibát (28D), hogy már a rajz alapjául szolgáló, az eredeti Perczel-glóbuszról készült nagy felbontású fényképek montírozásával előállított gömbkétszög sem volt jó, ugyanaz a fényképrészlet lett egymás mellé montírozva, kétszer. Az ezt a területet feldolgozó hallgató „megoldotta” a problémát, szó szerint „átvágta” a gordiuszi csomót: a csatlakozó szelvényhez illeszkedô módon futtatta a partvonalat: „kitalálta" milyen lehetett az 1862-ben, Perczel által megrajzolva (1. ábra).

Ey archivált ázsiai szelvényt nem tudtunk megnyitni (34É). Korábbi cötes anyagok alapjân sikerül elópedig Gede Mátyás által - a VGMben is szereplố 2012-es restaurált, digitális, tartalmi hasonmásból kinyert bitmap segítségével viszonylag gyorsan pótolhattuk (2. ábra). 


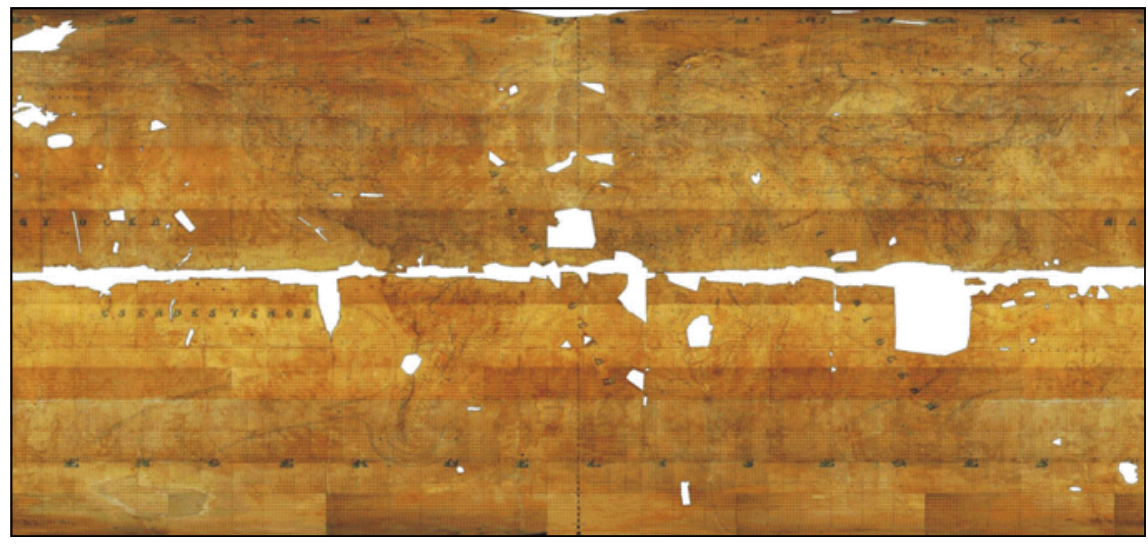

3. ábra. A Perczel-glóbusz Mercator-vetületú földgömbtérképe a sérült részek kiemelésével

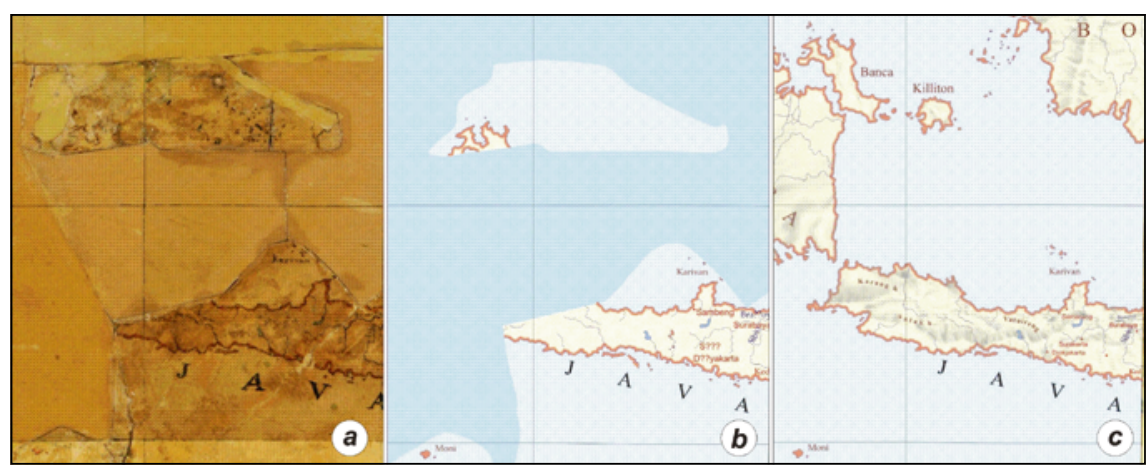

4. ábra. Az 1970-es évekbeli restaurálás hibája: a) A Perczel-gömb mai tartalma b) A 2012-es rajzi állapot; c) A 2019-es rekonstrukció rajza

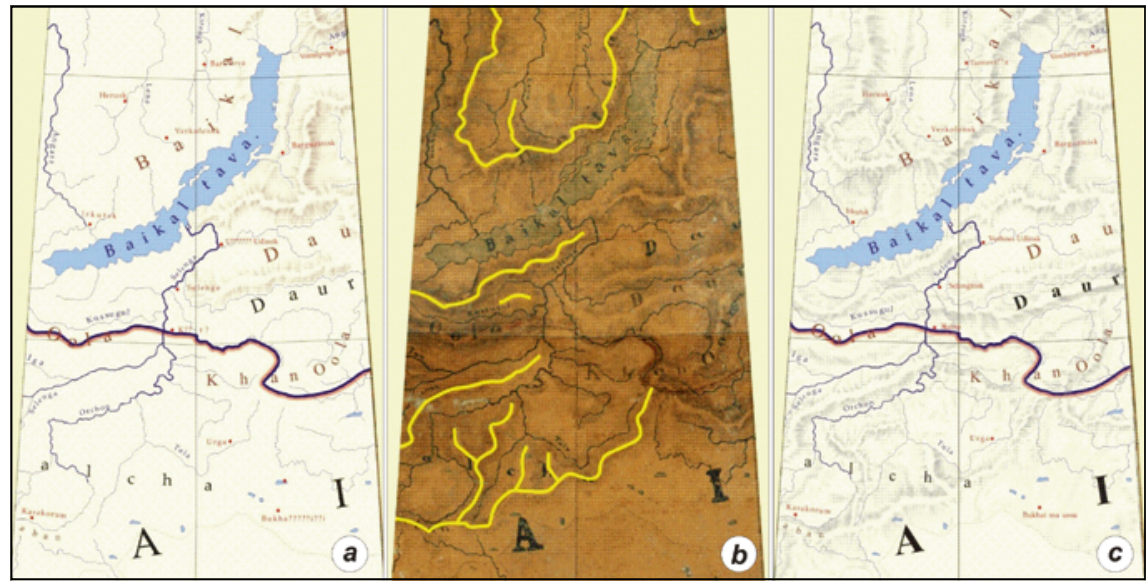

5. ábra. A Bajkál-vidék árnyékolt domborzatrajzának kiegészítési folyamata: a) A 2012-ben félbemaradt summer; b) Hegygerincek kijelölése a hiányzó részeken; c) A summerrel kiegészített rajzi tartalom

is megerôsítik -, hogy a Szumátrától keletre fekvô Banca szigetének maradék darabját rossz helyre kasírozták fel a gömbön (4. ábra).

Sziládi József, aki 2008 és 2012 között az árnyékolt domborzatrajzot (summert) önzetlenül, magas színvonalú munkával, szakmai elhivatottsággal, de ellenszolgáltatás nélkül (!) készítette, látásának romlása miatt nem tudta vállalni az akkor elmaradt munkarészek pótlását. A rendelkezésre álló idő rövidsége miatt magam magyar térképírás címú könyvében megemlített „1 milliós méretarányú, $132 \mathrm{~cm}$ átmérôjű Perczel-glóbusz” átmérôadatát. (Hogy 10 milliós, arra azonnal rájöttem!) Talán mentségemre szolgál, hogy ahol a magyar vagy a nemzetközi szakirodalomban Perczel földgömbjét említik, mindenhol a $132 \mathrm{~cm}$-es adat szerepel. Ám Perczel 1841-45 között a bécsi katonai akadémia, a K. K. Militärtechnische Hochschule hallgatójaként (AmbrusFallenbüchl 1963a) a felméréstan keretében bizonyára megismerhette az 1841-es Bessel-ellipszoid adatait (Timár 2018), amelyból 10 milliós méretarány mellett $127,5 \mathrm{~cm}$ egyenlítối átmérô adódik (a sarki 127,1cm). S valóban, a mai mérések szerinti gömbátmérô $127,5 \mathrm{~cm}$ !

\section{„Szellemek” a glóbuszon}

Két típusba sorolhatók ezek a rajzolatok a kéziratos Perczel-glóbuszon.

Vannak, amelyek sohasem léteztek, s talán korabeli leírások alapján (mint részben az egyenlítôi KözépAfrika területén futó folyók), esetenként pedig gyakran egyértelmúen forrástérképekből származóan szerkesztette a szerzô ezeket földgömbjére (Délkelet-Afrika „nagy tavai” vagy a Fülöp-szigetek keleti peremén fekvő St. Juan sziget). A Föld Perczel korában kevéssé ismert vagy teljesen ismeretlen részeirôl adnak „képet” ezek az ábrázolások. Természetesen megtartottuk ezeket, hiszen az eredeti glóbusz hiteles rajzi tartalmához tartoznak (6. ábra).

A másik típus bizonyíthatóan az elkészülés idôpontja (1862), de még inkább bizonyíthatóan nem Perczel László keze által (1897-ben bekövetkezett halála után) felkerült térképi tartalmat alkotja. Ezeket töröltük. Így például az „Éjszaki Jég Tenger” területéról az Orosz Birodalom szibériai partvidékénél levettük az 1913-ban felfedezett Szevernaja Zemlja (Északi-föld) szigetcsoport partvonalrajzát (29É, 30É, 31É) (7. ábra). Az idố rövidsége miatt ugyan nem volt mód Antarktika Perczel-korabeli partvonala pontos feltártságának vizsgálatára, vélhető azonban, hogy ott is történtek későbbi rajzi kiegészítések. 


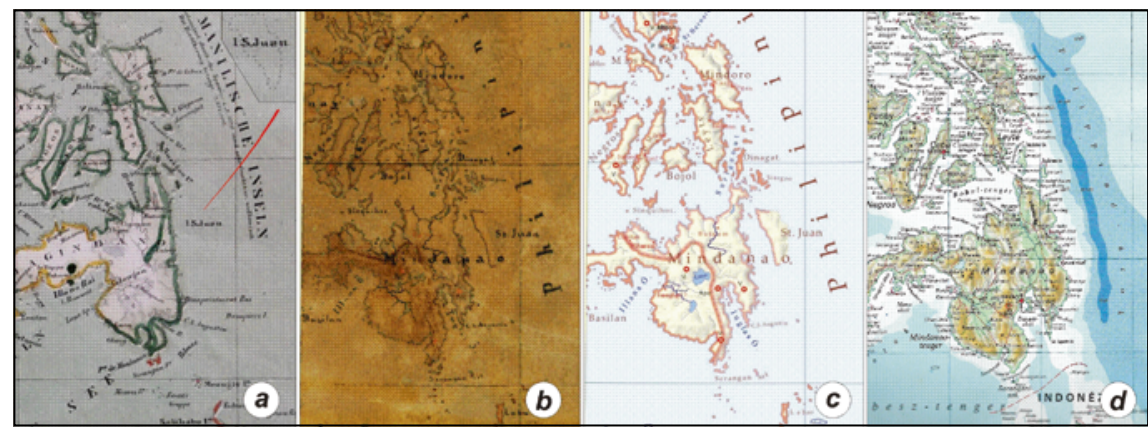

6. ábra. St. Juan szigete a Fülöp-szigetek keleti peremén: a) A feltételezett forrástérképen; b) A Perczel-glóbuszon; c) A 2019-es rajzi állapot; d) A Cartographia Világatlaszban

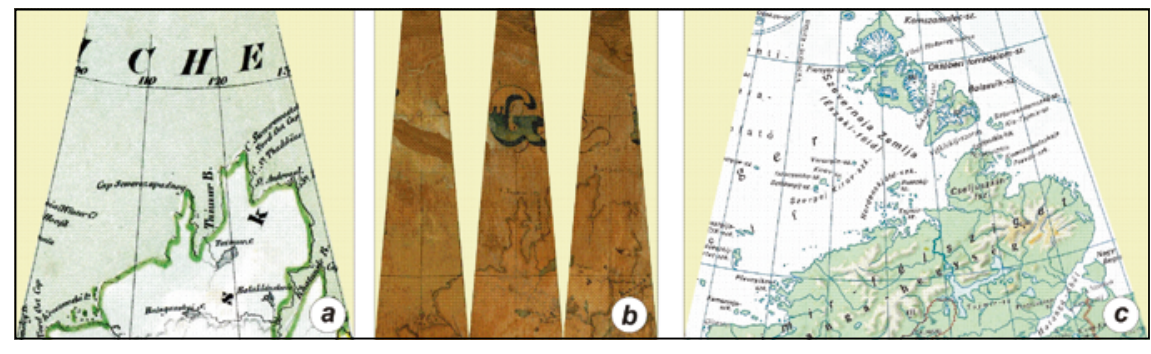

7. ábra. Szevernaja Zemlja partvonalrajza: a) A forrástérképen nem szerepel b) A Perczel-glóbuszon néhány kezdetleges vonal jelöli c) A Cartographia Világatlaszban

\section{Különleges rajzi megoldások}

Valószínú, hogy Perczel nem előre kidolgozott jelkulcsot követett munkája során, így kisebb-nagyobb különbségek mutatkoznak egyes térképelemek rajzi megjelenítésében. Mivel a gömb digitális restaurálása, illetve rekonstrukciója a cél, a sajátos rajzi, ábrázolásmódbeli megoldásokat megôriztük. Nézzünk néhány ilyen példát!

Az Ádeni-öböl északi partvidékén fekvô parti sávot (8. ábra) Perczel határozottan felülszínezte (25É). Ezzel a megoldással ebben a korban (de késóbb is) gyakran találkozunk a kartográfiai gyakorlatban a bizonytalan területi kiterjedésú, illetve a szárazföld belsejében még nem ismert (például
Afrikai nyugati partjai mentén fekvô) országok ábrázolása esetén.

Ugyanez az ábrázolás kiterjedtebb területen, mint EGYPTOM, NUBIA és KORODFAN határábrázolásánál (23É, 24É), Kogutowicz 1910-es $51 \mathrm{~cm}$ átmérójû́ glóbuszának képét idézi fel. A koronavonalat kísérô szokásos szélességú határbandot az országok belsố oldalán további, az elôzônél mintegy nyolcszor szélesebb, azzal azonos színú, de sokkal halványabb tónusú band követi, ilyen módon kettốs határbandot alkotva (9. ábra).

Az Everglades egy mocsárvidék Florida félszigetén (10. ábra), amelyet a glóbusz elkészülte óta csatornázással részben lecsapoltak, részben védett területté minősítettek (nemzeti park lett). Perczel kiemelten ábrázolta, tószerüen összefüggố vízfelületként, ám a tó sötétebb és a tenger világosabb vízfelületszíne közé esố kék tónussal színezte. Így nekünk is követni kellett ezt, a ma már a mocsaraknál szokatlan ábrázolásmódot (12É).

Hasonlóan érdekes, sajátos ábrázolás az ausztráliai „Lacus Torrens Sos to” (34D). Nagy kiterjedésú területe alapján feltételezhetjük, hogy a környező mocsárvilágot a sóstavakkal összevontan ábrázolja Perczel (11. ábra), ahogy az egykorú forrástérképek is teszik.

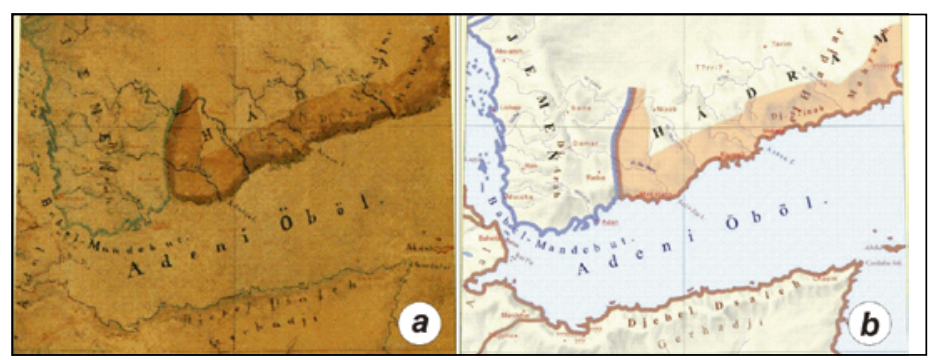

8. ábra. HÁDRAMAUTH nyugati része: a) A Perczel-gömbön; b) A 2019-es rajzi megoldás
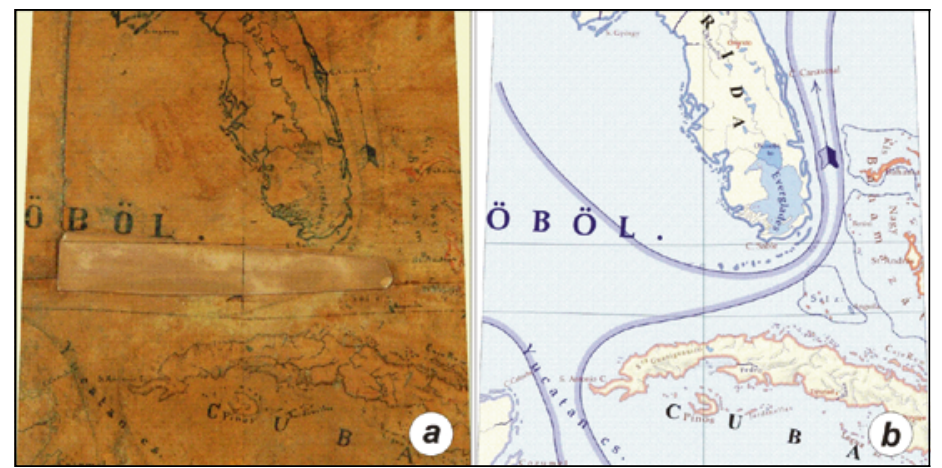

9. ábra. EGYPTOM és NUBIA sajátos határábrázolása (részlet): a) A Perczel-gömbön; b) A 2019-es rajzi megoldás

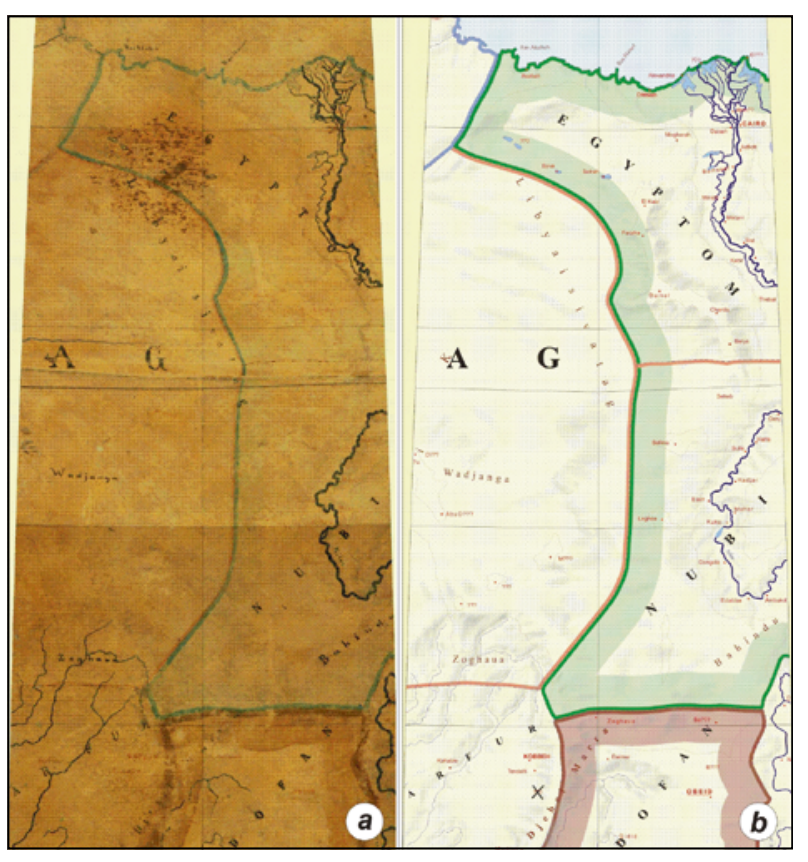

10. ábra. A floridai mocsárvidék egyedi ábrázolása: a) A Perczelgömbön; b) A 2019-es rajzi megoldás 


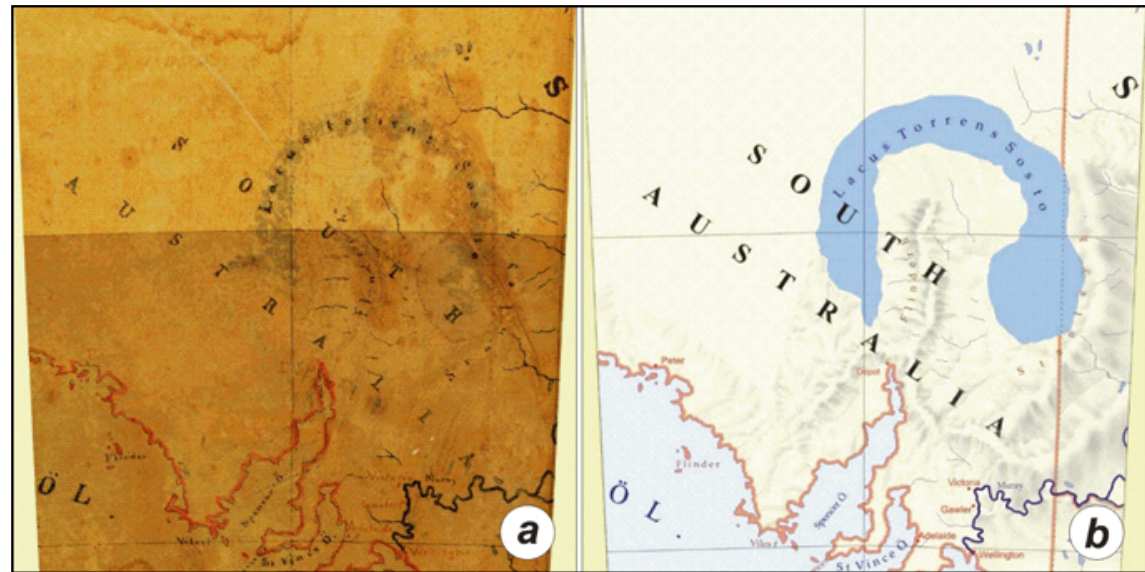

11. ábra. A „Lacus Torrens Sos to”: a) A Perczel-gömbön; b) A 2019-es rajzi megoldás

Gyermekkoromból még magam is emlékszem, hogy a fel nem tárt partszakaszok esetében a partvonalrajz egyszerúen megszakadt a térképeken

(12. ábra). Az északi területeken, különösen az észak-amerikai szigetvilág és Grönland egyes részein (18É) vagy Antarktika partvonalának 3 szelvényt

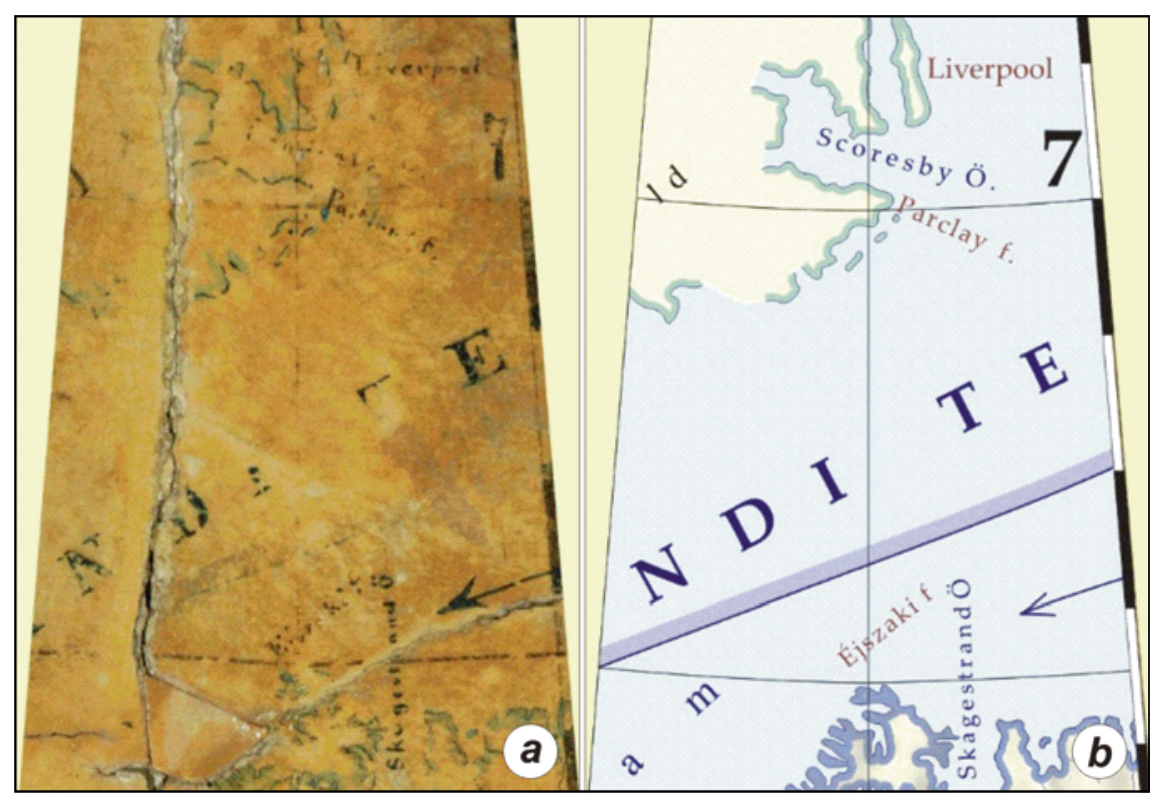

12. ábra. A grönlandi partvonal egyes részei (például a befagyott fjordok partjai) ismeretlenek, itt az ábrázolás „megszakad”: a) A Perczel-gömbön; b) A 2019-es rajzi megoldás
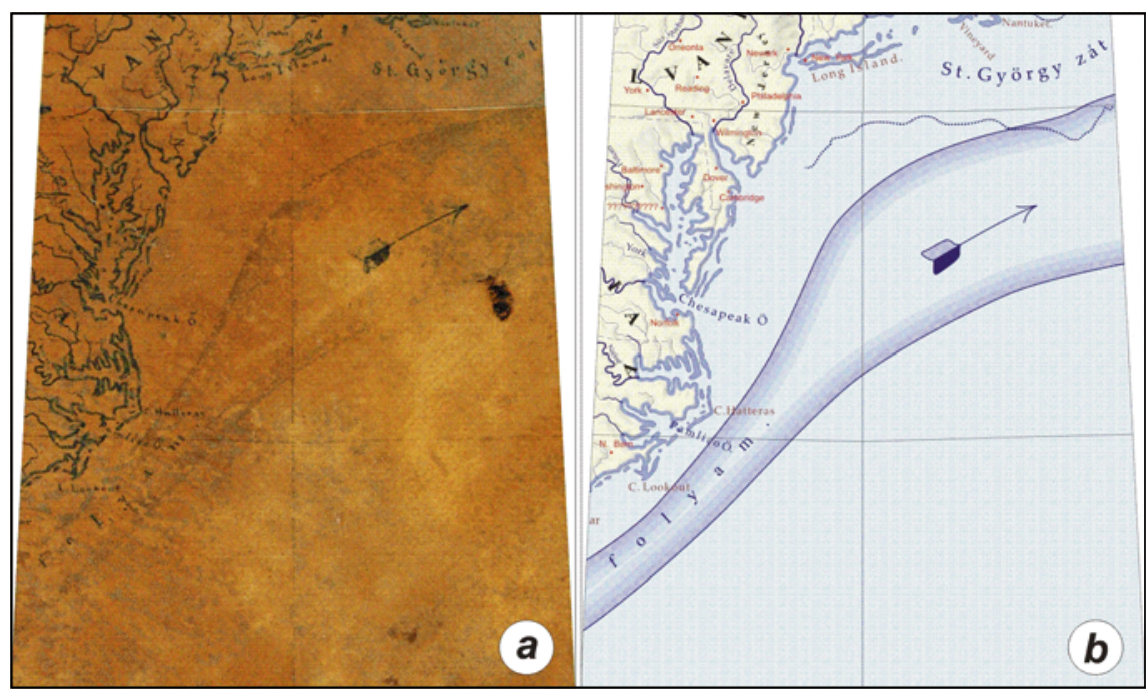

13. ábra. A tengeráramlások ábrázolása: a) A Perczel-glóbuszon; b) A 2019-es rajzi megoldás is érintô szakaszán a Perczel-glóbuszon is találkozunk ezzel a megoldással. Nem lett volna szerencsés mai ismereteink alapján kiegészíteni ezeket. Ezek elkülönítése azoktól, ahol a glóbusz súlyosabb sérülése miatt hiányzik a térképi tartalom, korabeli térképek segítségével viszonylag egyszerúen megoldható.

A tengeráramlás-ábrázolásra is sajátos rajzi megoldást alkalmazott Perczel. Az áramlás külsố határvonala mindkét oldalon egységesen egy folyamatos sötétkék vonal. Az áramlás belseje felé haladva ezt változó szélességú kék színú band kíséri. A széles területre kiterjedó áramlásterületeken gyakran több, egymással párhuzamos és egymáshoz illeszkedô band is található, amelyek kék tónusa az áramlás belseje felé haladva fokozatosan gyengül (13. ábra). A bandok rendszerint nem töltik ki az áramlást teljes szélességében, annak középrégiójában a tenger általános világoskék színezése kap helyet, míg a tengelyben elhelyezett rajzos nyilakkal Perczel az áramlásirányokat jelöli.

\section{A felhasznált forrásmunkák}

Az idố rövidsége, a szoros határidő miatt nem volt mód a lehetségesnek tartott, Perczel által használtnak gondolt forrásmunkák kiterjedt elemzésére, feltárására. „Hozott anyagból" dolgoztunk, az ELTE Térképtudományi és Geoinformatikai Tanszéke Térképtárában fellelhetô, hasznosnak vélt atlaszok szolgáltak alapanyagul az elvégzendô munkához. Kiválasztásukban Verebiné Fehér Katalin és Kiss Veronika könyvtárosaink szaktudására támaszkodhattam. Az alábbi atlaszok voltak segítségünkre:

Universal-Handatlas (Heinrich Berghaus). Glogau, 1859 (A/61) - Az atlaszlapokat Perczel bizonyíthatóan használta a földgömb szerkesztésekor. Az igen nagyszámú rajzi egyezés, egyes térképlapok esetében a névrajz szinte maradéktalan átvétele - gyakran a német írásmód megtartásával -, mind e mellett szólnak. Egészen biztosan állítható, hogy az egyik alapvetô forrásmunka volt. Természetesen lehet 
ez a mú valamelyik előző kiadása is! Például az 1857-es „fünfte Aufrage”, vagy még korábbiak is.

Atlas complet du précis de la géographie universelle. Paris, 1812 (A/275) - Ezt a térképmúvet, illetve talán inkább valamelyik későbbi kiadásának atlaszlapjait is egyértelmúen használta munkája során Perczel. Afrika és a Déli-Csendes-óceán szigetvilága névrajzi kérdései eldöntésekor voltak segítségünkre.

Galetti Egyetemi Világrajza (Falk Miksa). Pesten, 1857 (A/177) - A Perczel-glóbusz készítésével egykorú, és - ami nagyon fontos -, magyar nyelvú kiadvány. Azt mondhatjuk, hogy térképekkel elég gazdagon illusztrált világleíró földrajzkönyv. Külön tanulmányt érdemelne a szövegben szereplő és a térképeken megjelenô földrajzi nevek tételes összevetése Perczel László múvével.

Ideal Reference Atlas of the World. Chicago, 1907 (A jelzete nincs) Idóben messze a földgömb szerkesztése utáni kiadásról van szó. Bár léteztek korábbi kiadásai, a Perczelglóbusszal egykorút nem találtam. Mi elsôsorban az észak-amerikai kontinens településnévrajza „névsejtései”nek alátámasztására használtuk.

Andrees Handatlas. Bielefeld und Leipzig, 1896 (A/13) - Az elsô kiadása 1881-ben látott napvilágot, közel húsz esztendôvel a glóbusz elkészültét követốen, tehát Perczel nem használhatta. Tartalmi és névrajzi gazdagsága azonban sok kérdés megoldásához nyújtott segítséget munkánk során.

Nagy Magyar Atlasz [Dr Brózik Károly (szerk.)]. Lampel $R$. Könyvkereskedése, Budapest, 1906 (A/108) - Korábbi kiadásai nem voltak, így értelemszerúen Perczel sem használhatta. Magyaros írásra törekvố névhasználata miatt forgattuk, esetenként.

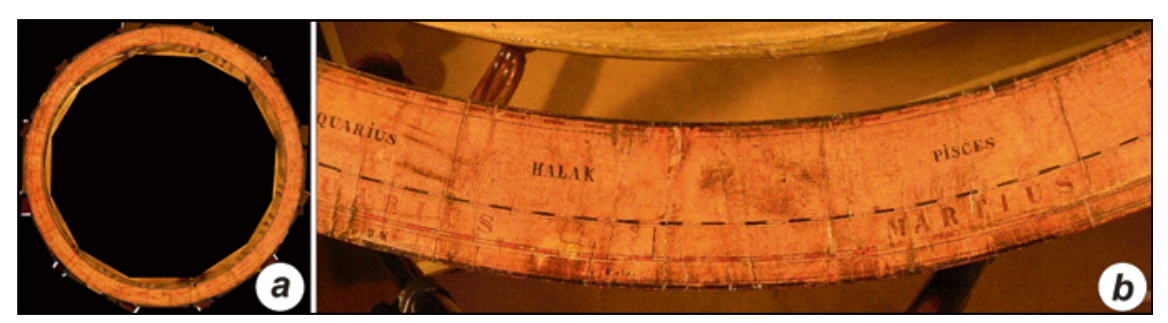

14. ábra. Az „összerakott” naptárkeret vagy horizontkör (a) és egy részlete (b)

A fentiekben néhány mondattal jellemzett múveken túl számos modern atlasz is segítette munkánkat. Néhány kiadványt érdemes is megemlíteni ezek közül: az Atlas on seismicity and volcanism (Swiss Re, Zürich, 1978), a vulkánok azonosításához, The Times Comprehensive Atlas of the World (Times Books, London, 2000) és The Macmillan World Atlas (Macmillan, New York, NY, USA, 1996) rajzi és névrajzi kérdések eldöntéséhez szolgált segítségül. Meglepô módon, elsősorban ugyancsak a névrajzi kérdések megoldásában igen jól használhatók voltak a Kartográfiai Vállalat elsố világatlaszai: Világatlasz (Bp., 1959) és Politikai és Gazdasági Világatlasz (Bp., 1961). És végül, de nem utolsó sorban, nagy segítséget jelentett számunkra a Webster's Geographical Dictionary (G. \& C. Merriam Co., Springfield, Mass., U.S.A., 1949) is.

\section{A naptárkeret}

A 2019-es munkákhoz kapcsolódóan elkészült a naptárkeret feldolgozása is: a nagy felbontású fotókat Nemes Zoltán készítette, a digitális montírozást Gede Mátyás végezte (14. ábra).

Perczel naptárkerete (horizontköre) bentrôl kifelé haladva a következôket tartalmazza:

1. kör: 1 fokos fokhálózat-beosztás (összesen 360 fok). A NYUGAT ponttól induló ún. létrás beosztás, bal felé üres, jobb felé tele vörös „téglalappal” kezdôdik. (A „téglalapon” itt és a továbbiakban is - pontosabban fogalmazva körgyưrűszelet értendő. Egykor „létrás” beosztásnak nevezték az egyenközú beosztást a kartográfus szakmában dolgozók. Ilyen pl. az Egyenlítô vagy a kezdômeridián, illetve a mértéklécek/ aránymértékek rajzi megjelenítése.)

2. kör: A NYUGAT ponttól induló fokszámmegírás. Ott 0 , tôle jobbra és balra is 10 fokonként megírva.
3. kör: Állatövi jegyek beosztása. A 12 mezó szerkezetét szemléltesse a Szúz jegye, a NYUGAT ponttól balra fekvő mezóben: SZÜZ; kép és jel; VIRGO.

4. kör: Az állatövi jegyekhez tartozó fokok száma szerinti ún. létrás beosztás (összesen 360 „téglalap”). A NYUGAT ponttól indul, bal felé üres, jobb felé tele fekete „téglalappal”. A Szűz-jegye (a NYUGAT ponttól balra) esetében a fokok megírása: 30 (0); 10; 20; 30 a 3. kör alján elhelyezve. A tavaszponttól (KELET) elindulva sorolom fel - Perczel írásmódját követve - az állatövi jegyeket, zárójelben megadva a hozzájuk tartozó naptári időszakokat. Az olvasónak nem kell hangsúlyoznom, hogy ezek kezdete nem az adott naptári nap 0 órájakor kezdódik. A jegyek tehát:

KOS - ARIES (március 21 - április 20.); BIKA - TAURUS (április 21. - május 21.); IKREK-GEMINI(május 22. - június 21.); RÁK - CANCER (június 22. - július 22.); OROSZLÁN - LEO (július 22. - augusztus 23.); SZÜZ - VIRGO (augusztus 24. szeptember 22.); MÉRLEG - LIBRA (szeptember 23. - október 23.); OLLÓS - SCORPIUS (október 24. - november 22.); NYILAS - SAGITTARIUS (november 23. - december 21.); BAK - CAPRICORNUS (december 22. január 20.); VIZÖNTÖ - AQUARIUS (január 21. - február 19.); HALAK PISCES (február 20. - március 20.).

5. kör: Üres.

6. kör: A hónapok neve (latinul), például: SEPTEMBER.

7. kör: A hónap napjainak beosztása: ún. létrás beosztás (összesen 365 üres és tele „téglalap”). A példaként szolgáló SEPTEMBER esetében a napok megírása: 31. (0); 10; 20; 30. a 6. kör alján elhelyezve (mivel az augusztus 31 napos). A hónapnevek fekete kontúros színezett betúkkel megírtak, és rendszerint a hozzájuk tartozó napok tele „téglalap”-jai is ugyanolyan színúek. Perczel írásmódját követve: JANUARIUS 31 (vörös), FEBRUARIUS 28 (vörös), MARTIUS 31 (vörös), APRILIS 30 (üres - esetleg sárga lehetett, csak a besötétedő védô lakkréteg „elnyelte”), MAJUS 31 (vörös), JUNIUS 30 (üres - a „téglalapok" a hó elsô napjainál vörösek), JULIUS 31 (vörös), AUGUSTUS 31 
(sötétbarna - a „téglalapok” részben vörösek), SEPTEMBER 30 (vörös), OCTOBER 31 (zöld), NOVEMBER 30 (vörös), DECEMBER 31 (zöld). (Összesen 365 nap.)

Figyelem! Az állatövi mezôk határai az 1. kör fokbeosztásához illeszkednek pontosan, és nem a hónapok napjaihoz, hiszen a Nap áthaladása a tavasz- vagy az ószponton nem

szükségszerúen 0 órakor történik! A Perczel-gömbön az ószponti áthaladás (ôszi napéjegyenlôség) szeptember 22-én kb. 18 óra 15 perckor lehetett (a naptárkeret szerint). Ez az időpont esik egybe a NYUGAT ponttal (0 fok).

A 365 kis „téglalap” azt jelenti, hogy 360/365 fokkal, azaz 0,9863 fokkal kell a kör sugarát elforgatni, hogy a napok

1. táblázat.
\begin{tabular}{|c|c|c|c|c|c|}
\hline $\begin{array}{c}\text { Angol } \\
\text { röv. }\end{array}$ & $\begin{array}{c}\text { Angol } \\
\text { irányok }\end{array}$ & $\begin{array}{c}\text { Magyar } \\
\text { röv }\end{array}$ & $\begin{array}{c}\text { Magyar } \\
\text { irányok }\end{array}$ & $\begin{array}{c}\text { PERCZEL } \\
\text { (elméleti) }\end{array}$ & $\begin{array}{c}\text { PERCZEL } \\
\text { (valós) }\end{array}$ \\
\hline N & north & É & észak & ÉJSZAK & ÉJSZ?? \\
\hline NbW & north by west & & & Nyugathozi É. & ??? \\
\hline NNW & north-northwest & ÉÉNy & észak-északnyugat & É.É. Ny & OK \\
\hline NWbN & northwest by north & & & É.N. Éjszak & OK \\
\hline NW & northwest & Ény & északnyugat & ÉJSZAKNYUGAT & OK \\
\hline NWbW & northwest by west & & & Nyugathozi É.N. & OK \\
\hline WNW & west-northwest & NyÉNy & nyugat-északnyugat & N.É. Nyugat & OK \\
\hline WbN & west by north & & & Éjszakhozi N. & OK \\
\hline W & west & Ny & nyugat & NYUGAT & OK \\
\hline WbS & west by south & & & Délhezi N. & OK \\
\hline WSW & west-southwest & NyDNy & nyugat-délnyugat & N.D. Nyugat & N.? Nyugat \\
\hline SWbW & southwest by west & & & Nyugathozi D.N. & OK \\
\hline SW & southwest & DNy & délnyugat & DÉLNYUGAT & OK \\
\hline SWbS & southwest by south & & D.N. Dél & OK \\
\hline SSW & south-southwest & DDNy & dél-délnyugat & D.D. Nyugat & OK \\
\hline SbW & south by west & & Nyugathozi D. & Ny????? \\
\hline S & south & D & & DÉL & ??? \\
\hline
\end{tabular}

\begin{tabular}{|c|c|c|c|c|c|}
\hline $\begin{array}{c}\text { Angol } \\
\text { röv. }\end{array}$ & $\begin{array}{c}\text { Angol } \\
\text { irányok }\end{array}$ & $\begin{array}{c}\text { Magyar } \\
\text { röv }\end{array}$ & $\begin{array}{c}\text { Magyar } \\
\text { irányok }\end{array}$ & $\begin{array}{c}\text { PERCZEL } \\
\text { (elméleti) }\end{array}$ & $\begin{array}{c}\text { PERCZEL } \\
\text { (valós) }\end{array}$ \\
\hline N & north & É & észak & ÉJSZAK & ÉJSZ?? \\
\hline NbE & north by east & & & Kelethezi É. & OK \\
\hline NNE & north-northeast & ÉÉK & észak-északkelet & OK \\
\hline NEbN & northeast by north & & & É.K. Éjszak & OK \\
\hline NE & northeast & ÉK & északkelet & ÉJSZAKKELET & OK \\
\hline NEbE & northeast by east & & & Kelethezi É.K. & ?ethezi É ? \\
\hline ENE & east-northeast & KÉK & kelet-északkelet & K.É. Kelet & OK \\
\hline EbN & east by north & & & Éjszakhozi K. & ??? \\
\hline E & east & K & kelet & KELET & ??? \\
\hline EbS & east by south & & & Délhezi K. & ??? \\
\hline ESE & east-southeast & KDK & kelet-délkelet & K.D. Kelet & ??? Kelet \\
\hline SEbE & southeast by east & & & Kelethezi D.K. & OK \\
\hline SE & southeast & DK & délkelet & DÉLKELET & OK \\
\hline SEbS & southeast by south & & Dél-délkelet & D.D. Kelet & ??? \\
\hline SSE & south-southeast & DDK & Kelethezi D. & ??? \\
\hline SbE & south by east & & DÉL & ??? \\
\hline S & south & \multirow{2}{*}{ ? } & & Iél & \\
\hline
\end{tabular}

határoló vonalait megkapjuk. A kezdôpont pedig a szeptember 22-ét jelölő napnak kb. 3/4-énél van.

\section{8. kör: Üres.}

9. kör: Égtájmegírások. NYUGAT: a megírás a 0 foktól (1. sor) két oldalra szimmetrikusan helyezkedik el. Balra haladva 90 foknál van ÉJSZAK, 180 foknál KELET. Jobbra haladva 90 foknál van DÉL. Mindig a megírás középvonala mutatja az adott irányt, a megíráshoz tartozó 11,25 fokos körgyúrú́szelet (ez van jelölve) felezóvonala (ez nem jelölt). A NYUGAT megíráshoz tartozó körgyúrúszelet tehát a 0 foktól mindkét irányban 5,625 fokig (5 fok 37,5 perc) terjed. Innen tovább már 11,25 fokokat (11 fok 15 perc) felmérve kapjuk a körgyúrúszeletek határvonalát. A mai gyakorlatban magát az égtáj irányát szokás jelölni.

Perczel 32 égtájat ad meg. A magyar nyelvben általában a négy fô égtáj (észak - É, kelet - K, dél - D, nyugat - Ny) mellett a(z ezeket felezó) másodrendú égtájakat (északkelet ÉK, délkelet - DK, délnyugat - DNy, északnyugat - ÉNy), illetve a (további felezéssel keletkezô) harmadrendú égtájakat (észak-északkelet - ÉÉK, kelet-északkelet - KÉK stb.) szokás megnevezni. Perczel jelöli a negyedrendú égtájakat is (I. táblázat). A mai beszélt nyelvben ezeket nem használjuk. A naptárkeret éppúgy sérüléseket szenvedett, mint maga a glóbusz. A táblázatban a „PERCZEL (valós)” oszlop a kiolvasható neveket, névtöredékeket, míg a „PERCZEL (elméleti)” oszlop a nevezékrendszer alapján kikövetkeztetett megírásokat tartalmazza. Ez utóbbiak kerültek a rekonstruált naptárkeretre.

10. kör: Üres.

Hogy a korábbi pontatlan ismereteket helyre tegyük, megemlítem, hogy Ambrus-Fallenbüchl (1963a) korábban is idézett - egyébként nagyon fontos - tanulmányában a naptárkeretre vonatkozó adatok hibásan szerepelnek: „A földgömbnek naptárkerete is van, mely szintén igen szép kidolgozású. Az állatöv jegyei a keret felső, $10 \mathrm{~cm}$ széles lapján pergamenpapírra vannak rajzolva és finoman színezve. Mellettük ott áll az illetô jegyek neve, a hónapok neve (napi beosztással) 


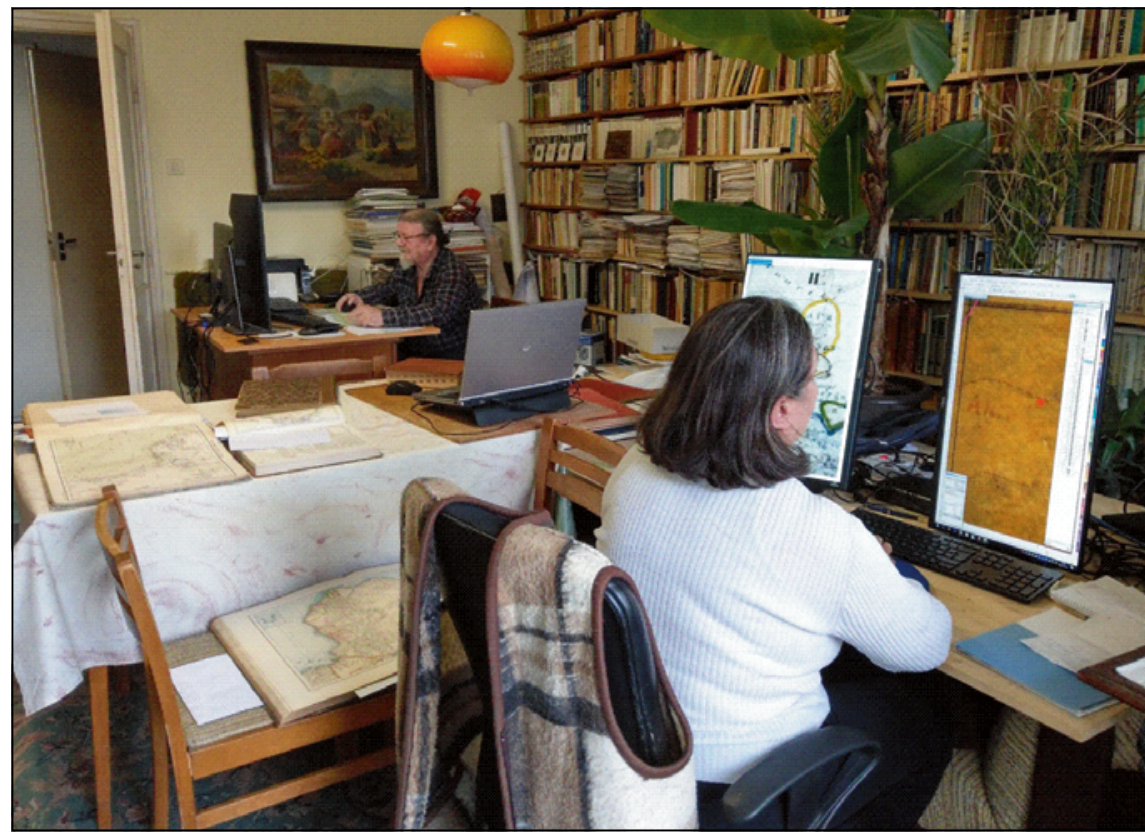

15. ábra. A Kovács Béla kollégám által összeállitott, a projektet lebonyolitó cég biztositotta gépeken folyik a munka a 2019-es Perczel-részprojektben

továbbá az égtáj megjelölése magyar és latin nyelven."

Mint láttuk, az égtájmegjelölések csak magyarul szerepelnek!

\section{Az eredmények}

Statisztikai módon összegezve az elmúlt közel hat hónapban végzett munka eredményeit:

- 72 cdr-formátumú gömbszegmens (fél gömbkétszög) 2012-es állapotra hozása. (Tételes vizsgálat - összevetés a Perczel-glóbuszról készített fényképekból összeállított, gömbi vetületbe transzformált bitmapekkel, azaz rajzi és névrajzi helyesbítések, kiegészítések összeállítása.) Ennek során összesen 2872 rajzi és 3252 névrajzi kiegészítés történt.

- 35 summert tartalmazó fájl készült az északi féltekére és 25 summert tartalmazó fájl a déli féltekére.

- 77 summer szürke színre történô cseréjére, beillesztésére került sor a fenti fájlokba, ezen túlmenően pedig 318 helyen, zömmel a glóbusz sérült részein került sor a summer pótlására, illetve kiegészítésére.

\section{Továbblépés}

Jelenleg egy újabb, a 2019-es kutatási eredményeket is tartalmazó virtuális Perczel-glóbusz előkészítésén dolgozom. Tervezem diplomamunka kiírását a névrajzi rekonstrukció mintaterületen való elvégzésére. Ennek folytatásaként pedig doktori témakiírást tervezek a lehetséges további források feltárására, a teljes névrajzi rekonstrukció elvégzésére, támaszkodva például a Falk Miksa-féle és a Perczel László-féle magyar nyelvú földrajzi nevek használata sajátosságainak feltárására, névrajzi keresôrendszer kiépítésére a Perczel-gömbhöz a VGM-en belül, amely tartalmazza a glóbusz neveinek mai magyar és nemzetközi átírású névváltozatait is, mint kereshetô elemeket.

\section{Köszönetnyilvánítás}

Mindenekelôtt az anonim szponzornak tartozom köszönettel, aki végsó soron lehetôvé tette az adott céggel való szerzódéskötésemet, és köszönöm a cégvezetônek, hogy engem választott partnerül a munka folytatására. Köszönettel tartozom feleségemnek, Paksi Juditnak, aki - mint mindig - most is segítôtársam volt. Kovács Béla kollégámnak a technikai háttér összeállításáért, beszerzéséért és üzembe helyezéséért jár köszönet. Ezek nélkül a projekt határidőre nem készült volna el. Itt köszönöm meg Verebiné Fehér Katalin, Kiss Veronika, Gede Mátyás és Nemes Zoltán önzetlen segítségét, valamint Zentai László támogatását is.

\section{Irodalomjegyzék}

Ambrus-Fallenbüchl Zoltán 1963a Magyarország legnagyobb földgömbje száz éves.

Geodézia és Kartográfia, 15. évf., 1. szám, pp. 61-62.

Ambrus-Fallenbüchl Zoltán 1963b. Der grösste Erdglobus Ungarns - hundert Jahre alt. Der Globusfreund, Publ. Nr. 12, Wien

Hegedüs Ábel 2019. szóbeli közlés

Lente Zsuzsanna: Restaurátori munka a Perczel-glóbusz újraalkotásában. Régi és új Perczel-glóbuszok: egy óriásgömb és rekonstrukciója. OSZK-ELTE-konferencia 2012. november 16. http://lazarus.elte.hu/ hun/buszke/2012-perczel/12.pdf

Márton Mátyás 2007. Föld-(és ég-) gömbök 3D-s előállítása (Virtuális Földgömbök Múzeuma és digitális virtuális restaurálás). Kutatási terv. Kézirat, ELTE Térképtudományi és Geoinformatikai Tanszék, Budapest, p. 6

Márton Mátyás - Gede Mátyás - Zentai László 2008. Föld- (és ég-) gömbök 3D-s elóállítása (Virtuális Földgömbök Múzeuma és digitális virtuális restaurálás). Geodézia és Kartográfia, 60. évf. 1-2. szám, pp. 42-48.

Márton Mátyás 2008. Egy elfeledett magyar csoda: Perczel László földgömbje - az elsó „világtérképmư”? Geodézia és Kartográfia, 60. évf. 3. szám, pp. 9-16 http://real.mtak.hu/4785/1/1123276.pdf

Márton Mátyás 2011a. Szakmai záróbeszámoló a Föld- (és ég-) gömbök 3D-s elóállítása (Virtuális Földgömbök Múzeuma és digitális virtuális restaurálás) címú kutatási témáról.

OTKA nyilvántartási száma: K 72 104. http:// real.mtak.hu/12181/1/72104 ZJ1.pdf

Márton Mátyás 2011b. A Perczel-földgömb újraalkotása. Néhány szó a glóbuszokról. OSZKELTE-konferencia 2011. március 18. http:// lazarus.elte.hu/hun/buszke/2011 -fold-eseggomb/konf.htm (lásd az elốadásokat)

Márton Mátyás 2012a. A Perczel-glóbusz újraalkotásának állásáról. MFTTT-előadás 2012. május 17. http://lazarus.elte.hu/hun/ hunkarta/mfttt-kartografiai-szakosztaly/ kartografiai.htm (lásd az elóadásokat)

Márton Mátyás 2012b. A Perczel-glóbusz újraalkotásáról (A projekt). Régi és új Perczelglóbuszok: egy óriásgömb és rekonstrukciója. OSZK-ELTE-konferencia 2012. november 16. http://lazarus.elte.hu/hun/ buszke/2012-perczel/04.pdf

Timár Gábor 2018. A Föld alakjának ismerettörténete - az archív térképek georeferálásának geofizikai alapja. MTA doktori értekezés. Budapest. https://drive google.com/file/d/1VU8EW6aibB2uHbhW Uq3xPBQotwqGHj1k/view

Verebiné Fehér Katalin 2019. szóbeli közlés

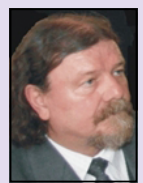

\section{Dr. Márton Mátyás professor emeritus az MTA doktora}

ELTE Térképtudományi és Geoinformatikai Tanszék matyi@map.elte.hu 